\title{
Apoptosis Inducing Activity of Fucoidan in HCT-15 Colon Carcinoma Cells
}

Jae-Hee Hyun, Sang-Cheol Kim, Jung-Il Kang, Min-Kyoung KIm, Hye-Jin Boo, Jung-Mi Kwon, Young-Sang KoH, Jin-Won Hyun, Deok-Bae PARK, Eun-Sook Yoo, and Hee-Kyoung Kang*

School of Medicine, Institute of Medical Sciences, Jeju National University; 66 Jejudaehakno, Jeju 690-756, South Korea. Received March 4, 2009; accepted July 8, 2009; published online July 16, 2009

\begin{abstract}
The antitumor activity of fucoidan from Fucus vesiculosus was investigated in human colon carcinoma cells. The crude fucoidan, a polysaccharide composed predominantly of sulfated fucose, markedly inhibited the growth of HCT-15 cells (human colon carcinoma cells). After HCT-15 cells were treated with fucoidan, several apoptotic events such as DNA fragmentation, chromatin condensation and increase of the population of sub-G1 hypodiploid cells were observed. In the mechanism of fucoidan-induced apoptosis, we examined changes in Bcl-2 and Bax protein expression levels and activation of caspases. Fucoidan decreased Bcl-2 expression, whereas the expression of Bax was increased in a time-dependent manner compared to the control. In addition, the active forms of caspase-9 and caspase-3 were increased, and the cleavage of poly(ADP-ribose) polymerase (PARP), a vital substrate of effector caspase, was observed. Furthermore, the induction of apoptosis was also accompanied by a strong activation of extracellular signal-regulated kinase (ERK) and p38 kinase and an inactivation of phosphatidylinositol 3-kinase (PI3K)/Akt in a time-dependent manner. These findings provide evidence demonstrating that the pro-apoptotic effect of fucoidan is mediated through the activation of ERK, p38 and the blocking of the PI3K/Akt signal pathway in HCT-15 cells. These data support the hypothesis that fucoidan may have potential in colon cancer treatment.
\end{abstract}

Key words fucoidan; HCT-15; apoptosis; bcl-2; ERK; p38 kinase

Fucoidan is a sulfated polysaccharide found in edible brown algae, such as Undaria pinnatifida, Fucus vesiculosus and Ecklonia cava. Fucoidan usually contains a large proportion of L-fucose and sulfate. Fucoidan has been reported to show various biological activities such as anti-tumor, ${ }^{1-4)}$ anti-coagulant, ${ }^{5,6)}$ anti-viral, ${ }^{7)}$ and anti-inflammatory. ${ }^{8)}$ Furthermore, its anti-tumor activity may be due to the inhibition of tumor angiogenesis in Ehrlich ascites carcinoma ${ }^{1)}$ and lung carcinoma, ${ }^{9)}$ as well as the direct induction of apoptosis in $\mathrm{U} 937^{3)}$ and HS-sultan cells. ${ }^{4)}$ Several marine algal polysaccharides, fucoidan in particular, have been found to induce apoptosis in cancer cells. ${ }^{10-12)}$ Nevertheless, there is no report on the effect of fucoidan in colon cancer, one of the most malignant neoplasias and a frequently occurring tumor in the world.

Recently, it has been demonstrated that the phosphorylation/de-phosphorylation states of some regulatory proteins are crucial events along the pathways controlling cell growth and apoptosis. A well-established apoptotic signaling cascade is regulated by mitogen activated protein (MAP) kinases. ${ }^{13)}$ The MAPK pathway consists of a three-tiered kinase core where MAP3K activates an MAP2K which in turn activates an MAPK (ERK, JNK; c-Jun N-terminal kinase, and $\mathrm{p} 38)$, resulting in the activation of nuclear factor- $\kappa \mathrm{B}$ $(\mathrm{NF}-\kappa \mathrm{B})$ and cell survival. ${ }^{14,15)}$ Akt signaling is another important transduction pathway that plays a critical role in controlling the balance between cell survival and apoptosis. ${ }^{16)}$

In this study, we investigated the effect of fucoidan on the induction of apoptosis in HCT-15 cells, human colon adenocarcinoma cells. Because MAPK and PI3K/Akt pathways are involved in cellular proliferation, differentiation, and apoptosis, ${ }^{17-20)}$ the phosphorylation and activities of two MAPKs, ERK and p38 MAPK as well as Akt were investigated. Understanding of the underlying mechanism of the induction of apoptosis by fucoidan will benefit the development of chemopreventive and/or chemotherapeutics for colon cancer.

\section{MATERIALS AND METHODS}

Fucoidan and Diallyl Disulfide Fucoidan (from Fucus vesiculosus) and diallyl disulfide (DADS) were purchased from Sigma (St. Louis, MO, U.S.A.). The fucoidan was dissolved in phosphate-buffered saline (PBS; Sigma, St. Louis, MO, U.S.A.) to $50 \mathrm{mg} / \mathrm{ml}$ and the DADS was dissolved in dimethylsulfoxide (DMSO; Sigma, St. Louis, MO, U.S.A.) to $50 \mathrm{~mm}$ at $-20^{\circ} \mathrm{C}$ until further use.

Cell Culture The HCT-15 human colon cancer cells were purchased from the Korea Cell Line Bank (KCLB) and cultured in RPMI1640 (Gibco BRL, Grand Island, NY, U.S.A.) medium supplemented with $10 \%$ fetal bovine serum (FBS) (Gibco BRL, Grand Island, NY, U.S.A.) at $37^{\circ} \mathrm{C}$ in a $5 \% \mathrm{CO}_{2}$ atmosphere. The exponentially growing cells were used throughout the experiments.

MTT Assay The 3-[4,5-dimethylthiazol-2-yl]-2,5-diphenyltetrazolium bromide (MTT) (Sigma, Saint Louis, MO, U.S.A.) assay was performed as previously described. ${ }^{21)}$ In brief, HCT-15 cells were cultured in a 96-well plate at a density of $1 \times 10^{5}$ cells per ml. The cells were then treated with $1,10,30,50$, and $100 \mu \mathrm{g} / \mathrm{ml}$ of fucoidan. After $3 \mathrm{~d}$, the cells were treated with $50 \mu \mathrm{l}$ MTT $(2 \mathrm{mg} / \mathrm{ml})$. Plates were incubated at $37^{\circ} \mathrm{C}$ for $4 \mathrm{~h}$, and the media was carefully aspirated. One-hundred and fifty microliters DMSO was then added to each well to dissolve the formazan crystals. The plates were read immediately at $540 \mathrm{~nm}$ on a microplate reader (Amersham Pharmacia Biotech., U.S.A.). All the experiments were performed three times, and the mean absorbance values were calculated. The results are expressed as the percentage of inhibition that produced a reduction in absorbance by fucoidan treatment compared to the untreated controls.

DNA Fragmentation Assay HCT-15 cells $\left(1 \times 10^{5}\right.$ 
cells $/ \mathrm{ml}$ ) were treated with $100 \mu \mathrm{g} / \mathrm{ml}$ of fucoidan for 6,12 and $24 \mathrm{~h}$. For the DNA fragmentation assay, the cells were collected by centrifugation, and DNA was extracted using the Wizard genomic DNA purification kit (Promega, Madison, WI, U.S.A.). The DNA fragmentation pattern was analyzed by electrophoresis on a $1.5 \%$ agarose gel containing $0.1 \mathrm{mg} / \mathrm{ml}$ ethidium bromide for $40 \mathrm{~min}$ at $100 \mathrm{~V}^{22}$ )

Flow Cytometric Analysis HCT-15 cells $\left(1 \times 10^{5}\right.$ cells $/ \mathrm{ml}$ ) were treated with $100 \mu \mathrm{g} / \mathrm{ml}$ of fucoidan for $12 \mathrm{~h}$ and $24 \mathrm{~h}$. For the flow cytometric analysis to determine cell cycle phase distribution, the treated cells were washed twice with PBS and fixed in $70 \%$ ethanol for $30 \mathrm{~min}$ at $4{ }^{\circ} \mathrm{C}$. The cells were then rinsed with PBS and incubated in $50 \mu \mathrm{g} / \mathrm{ml}$ propidium iodide solution (PI; Sigma) and $50 \mu \mathrm{g} / \mathrm{ml}$ RNase $\mathrm{A}$ in the dark for $30 \mathrm{~min}$ at $37^{\circ} \mathrm{C}$. Flow cytometry analysis was performed using an EPICS-XL FACScan flow cytometer (Coulter, Miami, FL, U.S.A.). The DNA histograms obtained were analyzed to measure the proportion of sub-G1 hypodiploid cells. $^{23)}$

Morphology Analysis HCT-15 cells $\left(1 \times 10^{5}\right.$ cells $\left./ \mathrm{ml}\right)$ were treated with $100 \mu \mathrm{g} / \mathrm{ml}$ of fucoidan for 12,24 and $48 \mathrm{~h}$. Cells were washed twice with PBS before being stained with $1 \mathrm{mg} / \mathrm{ml}$ Hoechst 33342 (H33342) for $30 \mathrm{~min}$ at $37^{\circ} \mathrm{C}$. Apoptosis with condensed and fragmented nuclei was observed with a fluorescence microscope $(\times 400$, BX-50, Olympus, Japan). ${ }^{24)}$

Western Blot Analysis HCT-15 cells $\left(1 \times 10^{5}\right.$ cells $\left./ \mathrm{ml}\right)$ were treated with $100 \mu \mathrm{g} / \mathrm{ml}$ of fucoidan for 12,24 , and $48 \mathrm{~h}$, as well as treated with $25 \mu \mathrm{M}$ of DADS, a positive reference compound for $24 \mathrm{~h}^{25)}$ After incubation, the cells were collected and washed twice with cold PBS. The cells were lysed in a lysis buffer [50 mM Tris- $\mathrm{HCl}(\mathrm{pH} 7.5), 150 \mathrm{~mm} \mathrm{NaCl}$, $1 \%$ Nonidet P-40, $2 \mathrm{~mm}$ ethylenediaminetetraacetic acid (EDTA), $1 \mathrm{~mm}$ ethylene glycol bis(2-aminoethyl ether)$N, N, N^{\prime}, N^{\prime}$,-tetraacetic acid (EGTA), $1 \mathrm{~mm} \mathrm{NaVO}_{3}, 10 \mathrm{~mm}$ $\mathrm{NaF}, 1 \mathrm{~mm}$ dithiothreitol, $1 \mathrm{~mm}$ phenylmethylsulfonyl fluoride, $25 \mu \mathrm{g} / \mathrm{ml}$ aprotinin, and $25 \mu \mathrm{g} / \mathrm{ml}$ leupeptin] and kept on ice for $30 \mathrm{~min}$. The cell lysates were centrifuged at $15000 \mathrm{rpm}$ at $4^{\circ} \mathrm{C}$ for $15 \mathrm{~min}$ and then until use, the supernatants were stored at $-70^{\circ} \mathrm{C}$. Protein concentration was measured using the Bradford method. ${ }^{26)}$ Aliquots of the lysates $(30-50 \mu \mathrm{g}$ of protein) were separated on a $12 \%$ sodium dodecyl sulfate (SDS)-polyacrylamide gel and transferred onto a polyvinylidene fluoride membrane (BIO-RAD, HC, U.S.A.) with a glycine transfer buffer [192 mm glycine, $25 \mathrm{~mm}$ Tris- $\mathrm{HCl}$ (pH 8.8), 20\% MeOH (v/v)]. After blocking the nonspecific site with $1 \%$ bovine serum albumin (BSA), the membrane was then incubated with a specific primary antibody at room temperature for $2 \mathrm{~h}$. The membrane was incubated with primary antibody against Bcl-2 (1:1000), Bax (1:1000), PARP $(1: 1000)$, caspase-3 (1:1000), caspase-9 (1:1000), ERK1/2 (1:1000), phospho-ERK1/2 (1:1000), p38 (1: 1000), phospho-p38 (1:1000), Akt (1:1000), phospho-Akt $(1: 1000)$ and $\beta$-actin $(1: 1000)$. and also incubated with a secondary horse-raddish peroxidase (HRP) antibody (1 : 5000; Vector Laboratories, Burlingame, U.S.A.) at room temperature. The membrane was exposed on X-ray films (AGFA, Belgium), and then the protein bands were detected using a WEST-ZOL ${ }^{\circledR}$ plus Western Blot Detection System (iNtRON, Gyeonggi-do, Korea).

Statistical Analysis Each experiment was performed at least in triplicate. Results are expressed as mean \pm S.D. from three separate experiments. Statistical significance was compared between each treated group and control by Dunnett's test and one-way ANOVA test (SPSS, version 12.0 for Windows; SPSS Inc., Chicago, IL, U.S.A.). *** $p<0.001$ compared with the control.

\section{RESULTS}

The Effect of Fucoidan on The Growth of HCT-15 Cells We studied the inhibitory effect of fucoidan on the growth of HCT-15 cells. When HCT-15 cells $\left(1.5 \times 10^{5}\right.$ cells $/ \mathrm{ml}$ ) were treated with $1,10,30,50$, and $100 \mu \mathrm{g} / \mathrm{ml}$ fucoidan for $3 \mathrm{~d}$, we found that fucoidan inhibited proliferation of HCT-15 cells by $1.8 \%, 24.3 \%, 49.8 \%, 54.0 \%$, and $62.0 \%$ respectively (Fig. 1). In the experiments thereafter, the cells were treated with $100 \mu \mathrm{g} / \mathrm{ml}$ of fucoidan and the apoptosis induction activity of the fucoidan was examined in timedependent manner.

The Effect of Fucoidan on Induction of Apoptosis in HCT-15 Cells DNA fragmentation, a hallmark of apoptosis, was detected by the DNA agarose gel electrophoresis method (Fig. 2A). DNA ladder bands were clearly detectable in HCT-15 cells treated with $100 \mu \mathrm{g} / \mathrm{ml}$ of fucoidan for over $12 \mathrm{~h}$. Furthermore, we quantified the cells in the sub-G1 population after treatment with fucoidan by flow cytometry analysis. When treated with $100 \mu \mathrm{g} / \mathrm{ml}$ fucoidan for $24 \mathrm{~h}$, the percentage of cells in the sub-G1 fraction increased by $56.1 \%$ (Fig. 2B). These results show that fucoidan induces apoptosis of HCT-15 cells and is supported by the increase in the number of apoptotic bodies which were easily found by H33342 staining in fucoidan-treated cells after over $24 \mathrm{~h}$ incubation (Fig. 2C).

To investigate the possible mechanism underlying the induction of apoptosis by fucoidan, we examined the expression of Bcl-2 and Bax in HCT-15 cells after treatment with fucoidan and DADS. The expression of Bax increased markedly, while the expression of Bcl-2 decreased in the cells treated with $100 \mu \mathrm{g} / \mathrm{ml}$ fucoidan in a time-dependent manner (Fig. 3A). The treatment with $25 \mu \mathrm{M}$ DADS for $24 \mathrm{~h}$ also increased the expression of Bax, but decreased Bcl-2 expression in HCT-15 cells (Fig. 3A). We then examined the activation of caspase cascade in HCT-15 cells treated with $100 \mu \mathrm{g} / \mathrm{ml}$ fucoidan. In response to fucoidan, the expressions of the active forms of caspase- 9 and caspase- 3 increased in a time-dependent manner. The activation of caspase- 3 was demonstrated by the proteolytic cleavage of PARP $(116 \mathrm{kDa})$

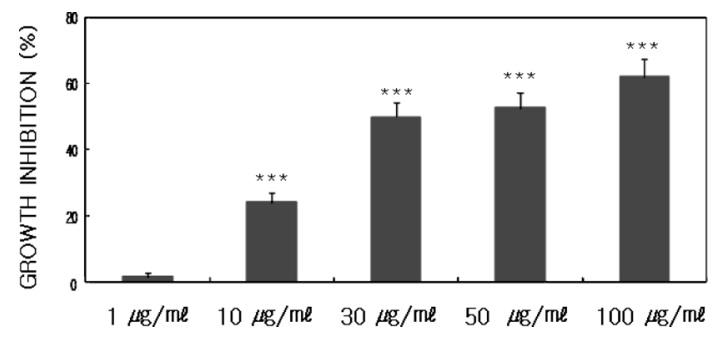

Fig. 1. Inhibitory Effect of Fucoidan on the Growth of HCT-15 Cells

The HCT-15 cells $\left(1.5 \times 10^{5}\right.$ cells $\left./ \mathrm{ml}\right)$ were treated with $1,10,30,50$, and $100 \mu \mathrm{g} / \mathrm{ml}$ of fucoidan for $3 \mathrm{~d}$ and measured for viability by MTT assay. All experiments were performed in triplicate. Data were presented as a mean \pm S.D. from three separate experiments. $* * * p<0.001$ compared with the control. 
A

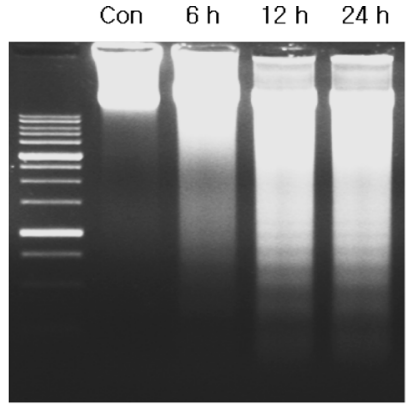

B

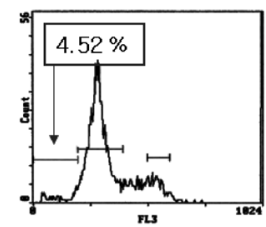

Con

C

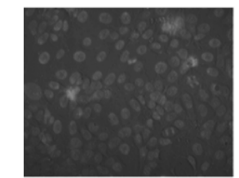

Con

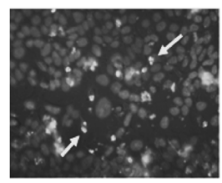

$24 \mathrm{~h}$
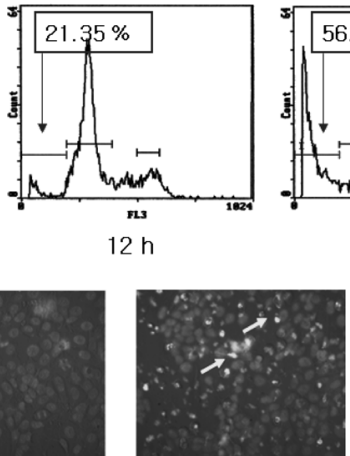

$12 \mathrm{~h}$

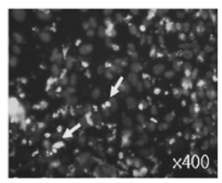

$48 \mathrm{~h}$

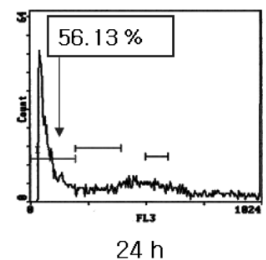

$24 \mathrm{~h}$
Fig. 2. Induction of Apoptosis by Fucoidan in HCT-15 Colon Cancer Cells

(A) DNA fragmentation by the fucoidan in HCT-15 cells. The HCT-15 cells $\left(1.5 \times 10^{5}\right.$ cells $\left./ \mathrm{ml}\right)$ were treated with $100 \mu \mathrm{g} / \mathrm{ml}$ of fucoidan for 6,12 and $24 \mathrm{~h}$. The DNA was isolated and subjected to $1.5 \%$ agarose gel electrophoresis and visualized with ethidium bromide staining. (B) The degree of apoptosis was represented as the DNA content measured by flow cytometric analysis in HCT-15 cells. The HCT-15 cells $\left(1.5 \times 10^{5}\right.$ cells $\left./ \mathrm{ml}\right)$ were treated with $100 \mu \mathrm{g} / \mathrm{ml}$ of fucoidan for 12 and $24 \mathrm{~h}$. The measurement of sub-G1 hypodiploid cells by flow cytometric analysis was performed as described in Materials and Methods. (C) The degree of apoptosis represented as the fluorescent image of nuclei in cells by fluorescent microscope. The HCT-15 cells $\left(1.5 \times 10^{5}\right.$ cells $/ \mathrm{ml}$ ) were treated with $100 \mu \mathrm{g} / \mathrm{ml}$ of fucoidan for 12,24 and $48 \mathrm{~h}$. DNA-specific fluorescent dye, H33342 $(1 \mathrm{mg} / \mathrm{ml})$, was directly added to $10 \mu \mathrm{g} / \mathrm{ml}$ in a final concentration, and the cells were photographed under inverted fluorescent microscope $(\times 400)$.

to $85-\mathrm{kDa}$ cleavage products (Fig. 3B). When treated with $25 \mu \mathrm{M}$ DADS for $24 \mathrm{~h}$, the active forms of caspase- 9 and caspase- 3 as well as the proteolytic cleavage form of PARP were observed. These results demonstrated that fucoidan induced apoptosis in HCT-15 cells through downregulation of Bcl-2 and activation of caspases as DADS, a positive reference compound.

Intracellular Signaling of Fucoidan-Induced Apoptosis To investigate fucoidan-induced intracellular signaling, we analyzed the phosphorylation of ERK and p38 as well as Akt pathways by Western blot. As shown in Fig. 4, treatment with $100 \mu \mathrm{g} / \mathrm{ml}$ fucoidan led to a strong activation of ERK and p38 kinase in a time-dependent manner. Phosphorylation of Akt kinase was clearly decreased by fucoidan treatment in a time-dependent manner (Fig. 4). The treatment with $25 \mu \mathrm{M}$ DADS, which is known to have an apoptosis inductive effect in the HCT-15 cell, also showed the activation of ERK and p38 kinase and inactivation of Akt (Fig. 4). Since inactivation of the Akt pathway was reported to be involved in the in-

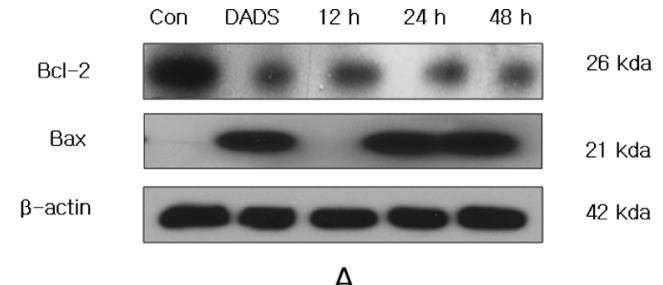

Con DADS $12 \mathrm{~h} \quad 24 \mathrm{~h} \quad 48 \mathrm{~h}$

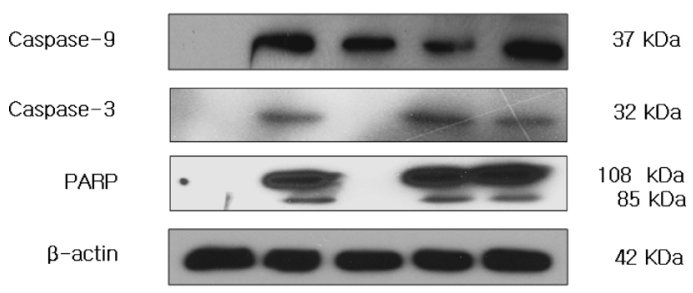

B

Fig. 3. Effect of Fucoidan on the Levels of Bcl-2 and Bax as Well as the Cleavage of Pro-caspase-9, Pro-caspase-3 and PARP

(A) Western blot analyses of Bcl-2 and Bax proteins. (B) Western blot analyses of caspase- 9 , caspase- 3 and cleavage of PARP proteins. The HCT-15 cells $\left(1.5 \times 10^{5}\right.$ cells $/ \mathrm{ml}$ ) were treated with $100 \mu \mathrm{g} / \mathrm{ml}$ of fucoidan for $6,12,24$, and $48 \mathrm{~h}$, and $25 \mu \mathrm{M}$ of diallyl disulfide (DADS) for $24 \mathrm{~h}$. Western blot analyses were performed as described in Materials and Methods. * DADS was used as a positive reference compound.

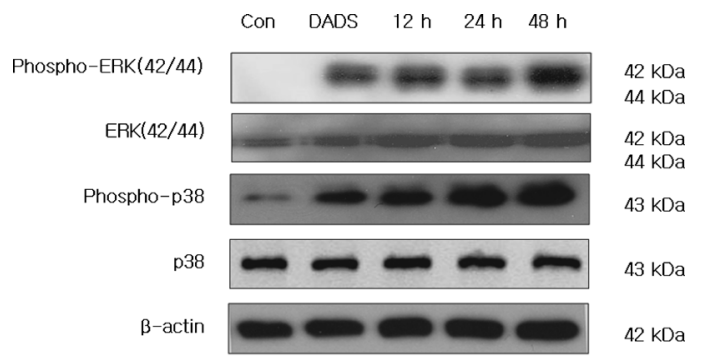

A

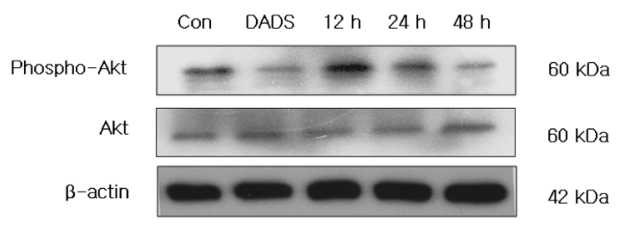

B

Fig. 4. Effect of Fucoidan on the Activation of MAP Kinases (ERK 1/ERK2 and p38) and PI3K/Akt

(A) Western blot analyses of phosphorylation of ERK1/ERK2 and p38. (B) Western blot analyses of phosphorylation of PI3K/Akt. The HCT-15 cells $\left(1.5 \times 10^{5} \mathrm{cells} / \mathrm{ml}\right)$ were treated with $100 \mu \mathrm{g} / \mathrm{ml}$ of fucoidan for 12,24 and $48 \mathrm{~h}$ and $25 \mu \mathrm{M}$ of dially disulfide (DADS) for $24 \mathrm{~h}$. Western blot analyses were performed as described in Materials and Methods. *DADS was used as a positive reference compound.

duction of apoptosis, it is likely that this downregulation of Akt by fucoidan contributed to fucoidan-induced apoptosis in HCT-15 cells.

\section{DISCUSSION}

Fucoidan is one of the major sulfated polysaccharides of brown seaweeds, and its sulfate group plays an important role in various biological activities. ${ }^{27-31)}$ In this study, we used a commercial available fucoidan purified from $F$. vesicu- 
losus. To our knowledge for the first time, we demonstrated fucoidan-induced apoptosis of HCT-15 colon cancer cells.

This study observed that fucoidan inhibited the proliferation of HCT-15 in a dose-dependent manner and the growth inhibition of HCT-15 cells in the treatment with $100 \mu \mathrm{g} / \mathrm{ml}$ fucoidan was $62 \% . \mathrm{IC}_{50}$ value for fucoidan was about $34 \mu \mathrm{g} / \mathrm{ml}$. However, the $100 \mu \mathrm{g} / \mathrm{ml}$ fucoidan barely inhibited the growth of HEL-299, which is a normal cell line, by under $5 \%$ (data not shown).

Today, we recognize that apoptosis or programmed cell death is the outcome of a complex interplay of pro- and antiapoptotic molecules. Pro-survival Bcl-2 and its helpers compete with Bax and other pro-apoptosis proteins to regulate the release of proteins and cytochrome $c$ from mitochondria, which in turn activate 'initiator' caspases including caspase9. ${ }^{32)}$ High levels of Bcl-2 expression have been found in several human tumors, and levels of Bcl-2 expression have been correlated with the aggressiveness of the malignancies. ${ }^{33}$ ) Bcl-2 has been shown to block cytotoxic agents, whereas the inhibition of Bc1-2 function, by Bcl-2 antisense oligonucleotides (ASO) for example, precipitates apoptosis. ${ }^{34)}$ Since Bcl-2 functions by forming a heterodimer with its pro-apoptotic partner Bax, the Bcl-2:Bax ratio is proportional to the relative sensitivity or resistance of the cells to various apoptotic stimuli. ${ }^{35)}$ Here, we showed that fucoidan reduced the Bcl-2 level, whereas the Bax level increased in HCT-15 cells. In response to fucoidan treatment, caspase-9 was activated leading to the activation of caspase-3, one of the key executioners of apoptosis. When HCT-15 cells were treated with fucoidan, the activation of caspase- 3 was demonstrated by the cleavage of PARP, a nuclear enzyme that is involved in DNA repair in response to various stresses. DADS, an important oil-soluble organosulfur component of garlic (Allum sativum), has been reported to inhibit the growth of human cancer cells such as colon, lung, skin and breast. ${ }^{36-38)}$ Moreover, DADS has been known to have an apoptosis inductive effect in the HCT-15 cell ${ }^{38)}$ and DADS was used as a positive reference compound in this study. Just as expected, the treatment with $25 \mu \mathrm{M}$ DADS for $24 \mathrm{~h}$ induced downregulation of Bcl-2 and activation of caspases in HCT-15 cells.

ERK and p38 MAPK are Ser/Thr kinases that are activated in a cascade-like fashion that is typical of members of the MAPK family. ERK is mostly associated with cellular survival and proliferation brought on by mitogenic inputs; 338 MAPK is activated by different types of cellular stress and is mostly associated with apoptotic cell death and differentiation. ${ }^{39,40)}$ However, ERK1/ERK2 sometimes showed an opposite biological effect. Epigallocatechin gallate (EGCG) and epigallocatechin (EGC), green tea catechins, induce apoptosis of HCT 116 through the activation of phosphorylation of ERK1/ERK2 and p38. ${ }^{41)}$ Akt, also a Ser/Thr kinase activated via a specific enzyme known as PI3 kinase, ${ }^{42,43)}$ is involved in cellular processes such as proliferation, differentiation and metabolism and is fundamental to cellular survival by means of suppression of apoptosis. Thus, strategies to block the activity of Akt would ideally lead to the inhibition of proliferation and induction of apoptosis. Previous studies have demonstrated that taxol induces apoptosis through activation of PI3K/Akt pathways. ${ }^{44,45)}$ In the present study, the apoptotic induction of fucoidan was also accompanied by phosphorylation of ERK and p38 as well as an inactivation of PI3K/Akt in a time-dependent manner. When treated with $25 \mu \mathrm{M}$ DADS for $24 \mathrm{~h}$, the activation of ERK and p38 kinase and inactivation of Akt were also observed. It has already been reported that fucoidan has direct anti-cancer effects on human HS-sultan cells through activation of caspase-3 and downregulation of ERK pathways. Moreover, DADS was demonstrated to induce apoptosis through the activation of ERK in human non-small cell lung carcinoma H1299 cells, while inhibition of ERK and activation of p38 by DADS were reported in apoptosis induction of HL-60 leukemia cells. ${ }^{46,47)}$

In summary, our studies demonstrate that fucoidan inhibited the growth of HCT-15 colon cancer cells by inducing apoptosis. Fucoidan induces apoptosis through the downregulation of Bcl-2 as well as the activation of pro-caspases- 9 and -3. Furthermore, the induction of apoptosis was also accompanied by strong activation of ERK and p38 kinase and an inactivation of PI3K/Akt in a time-dependent manner. These data support the hypothesis that fucoidan may have potential in colon cancer treatment.

Acknowledgements This work was supported by a Grant from the Brain Korea 21 program of the Korea Research Foundation (2008) and by a Grant from the Jeju National University Hospital Research fund (2008).

\section{REFERENCES}

1) Itoh H., Noda H., Amano H., Zhuaug C., Mizuno T., Ito H., Anticancer Res., 13, 2045-2052 (1993).

2) Maruyama H., Tamauchi H., Iizuka M., Nakano T., Planta Med., 72, 1415-1417 (2006).

3) Teruya T., Konishi T., Uechi S., Tamaki H., Tako M., Int. J. Biol. Macromol., 41, 221-226 (2007).

4) Aisa Y., Miyakawa Y., Nakazato T., Shibata H., Saito K., Ikeda Y., Kizaki M., Am. J. Hematol., 78, 7-14 (2005).

5) Durig J., Bruhn T., Zurborn K. H., Gutensohn K., Bruhn H. D., Beress L., Thromb. Res., 85, 479-491 (1997).

6) Trento F., Cattaneo F., Pescador R., Porta R., Ferro L., Thromb. Res., 102, 457-465 (2001).

7) Thompson K. D., Dragar C., Phytother. Res., 18, 551-555 (2004).

8) Cumashi A., Ushakova N. A., Preobrazhenskaya M. E., D’Incecco A., Piccoli A., Totani L., Tinari N., Morozevich G. E., Berman A. E., Bilan M. I., Usov A. I., UStuzhanina N. E., Grachev A. A., Sanderson C. J., Kelly M., Rabinovich G. A., Iacobelli S., Nifantiev N. E., Glycobiology, 17, 541-552 (2007)

9) Zhuang C., Itoh H., Mizuno T., Ito H., Biosci. Biotechnol. Biochem., 59, 563-567 (1995).

10) Sogawa K., Matsuda M., Okutani K., J. Mar. Biotechnol., 6, 241-243 (1998).

11) Aisa Y., Miyakawa Y., Nakazato T., Shibata H., Saito K., Ikeda Y., Kizaki M., Am. J. Hematol., 78, 7-14 (2005).

12) Teruya T., Konishi T., Uechi S., Tamaki H., Tako M., Int. J. Biol. Macromol., 41, 221-226 (2007).

13) Matsuzawa A., Ichijo H., Antioxid. Redox Signal, 7, 472-481 (2005).

14) Seger R., Krebs E. G., FASEB J., 9, 726-735 (1995).

15) Sebolt-Leopold J. S., Oncogene, 19, 6594-6599 (2000).

16) Kong A. N., Yu R., Hebbar V., Chen C., Owuor E., Hu R., Ee R., Mandleker S., Mutat. Res., 480-481, 231-241 (2001).

17) Philchenkov A., Zavelevich M., Imbs T., Zvyagintseva T., Zaporozhets T., Exp. Oncol., 29, 181-185 (2007).

18) Durig J., Bruhn T., Zurborn K. H., Gutensohn K., Bruhn H. D., Beress L., Thromb. Res., 85, 479-491 (1997).

19) Patankar M. S., Oehninger S., Barnett T., Williams R. L., Clark G. F., J. Biol. Chem., 268, 21770-21776 (1993).

20) Chevolot L., Mulloy B., Ratiskol J., Foucault A., Colliec-Jouault S., Carbohydr. Res., 330, 529-535 (2001).

21) Carmichael J., DeGraff W. G., Gazdar A. F., Minna J. D., Mitchell J. B., Cancer Res., 47, 943-946 (1987). 
22) Oberhammer F., Wilson J. W., Dive C., Morris I. D., Hickman J. A., Wakeling A. E., Walker P. R., Sikorska M., EMBO J., 12, 3679-3684 (1993).

23) Sherwood S. W., Sheridan J. P., Schimke R. T., Exp. Cell Res., 215, 373-379 (1994).

24) Montanaro F., Liadaki K., Schienda J., Flint A., Gussoni E., Kunkel L. M., Exp. Cell Res., 298, $144-154$ (2004).

25) Kwon K. B., Yoo S. J., Ryu D. G., Yang J. Y., Rho H. W., Kim J. S, Park J. W., Kim H. R., Park B. Y., Biochem. Pharmacol, 63, 41-47 (2002).

26) Bradford M. M., Anal. Biochem., 72, 248-254 (1976).

27) Riou D., Colliec-Jouault S., Pinczon du Sel D., Bosch S., Siavoshian S., Le Bert V., Tomasoni C., Sinquin C., Durand P., Roussakis C., Anticancer Res., 16, 1213-1218 (1996).

28) Itoh H., Noda H., Amano H., Zhuaug C., Mizuno T., Ito H., Anticancer Res., 13, 2045-2052 (1993).

29) Chida K., Yamamoto I., Kitasato Arch. Exp. Med., 60, 33-39 (1987).

30) Maruyama H., Tamauchi H., Hashimoto M., Nakano T., In Vivo, 17, $245-249$ (2003).

31) Koyanagi S., Tanigawa N., Nakagawa H., Soeda S., Shimeno H., Biochem. Pharmacol., 65, 173-179 (2003).

32) Hanahan D., Weinberg R. A., Cell, 100, 57-70 (2000).

33) Pettersson M., Jernberg-Wiklund H., Larsson L. G., Sundström C. Givol I., Tsujimoto Y., Nilsson K., Blood, 79, 495-502 (1992).
34) Heere-Ress E., Thallinger C., Lucas T., Schlagbauer-Wadl H., Wacheck V., Monia B. P., Wolff K., Pehamberger H., Jansen B., Int. J. Cancer, 99, 29-34 (2002).

35) Oltvai Z. N., Milliman C. L., Korsmeyer S., J. Cell, 74, 609-619 (1993).

36) Hong Y. S., Ham Y. A., Choi J. H., Kim J., Exp. Mol. Med., 32, 127 134 (2000).

37) Kwon K. B., Yoo S. J., Ryu D. G., Yang J. Y., Rho H. W., Kim J. S., Park J. W., Kim H. R., Park B. H., Biochem. Pharmacol., 63, 41-47 (2002).

38) Sundaram S. G., Milner J. A., Carcinogenesis, 17, 669-673 (1996).

39) Shi Y., Gaestel M., Biol. Chem., 383, 1519-1536 (2002).

40) Pearson G., Robinson F., Beers Gibson T., Xu B., Karandikar M., Berman K., Cobb M. H., Endocr. Rev., 22, 153-183 (2001).

41) Uesato S., Kitagawa Y., Kamishimoto M., Kumagai A., Hori H., Nagasawa H., Cancer Lett., 170, 41 - 44 (2001).

42) Scheid M. P., Woodgett J. R., FEBS Lett., 546, 108-112 (2003).

43) Nicholson K. M., Anderson N. G., Cell Signal., 14, 381-395 (2002).

44) Frenette P. S., Weiss L., Blood, 96, 2460-2468 (2000).

45) Sweeney E. A., Lortat-Jacob H., Priestley G. V., Nakamoto B., Papayannopoulou T., Blood, 99, 44-51 (2002).

46) Hui C., Jun W., Ya L. N., Ming X., Trop. Biomed., 25, $37-45$ (2008).

47) Tan H., Ling H., He J., Yi L., Zhou J., Lin M., Su O., Arch. Pharm Res., 31, 786-793 (2008). 